\title{
Evaluation of Medicinal Plant Trade Contribution, And Challenges Affecting Its Conservation in the Urban Livelihood of Ibadan and Ogbomoso Metropolis, Nigeria
}

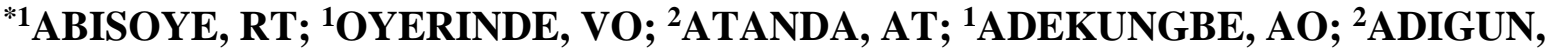 H}

\author{
${ }^{* 1}$ Department of Forestry and Wood Technology, Federal University of Technology Akure, Nigeria \\ ${ }^{2}$ Forestry Research Institute of Nigeria, Ibadan \\ *Corresponding Author Email: Abstem001@myuct.ac.za
}

\begin{abstract}
The extent of the medicinal plant trade is largely unaccounted for as records of sales transactions are seldom kept and the trade is often illicit in nature. The effect of this is usually on its conservation status due to several human activities such as overharvesting and deforestation. This study shows that 1 . The income from the trade of medicinal plants contributed to their income level in both metropolises. 2 . The people mostly obtained their medicinal plants from the forest which came first in position, and grazing lands as second. 3) Plant collection for them is easy (because they do have information on where to get it) and difficult which is because of changes in land use and overexploitation (as the distance get farer). According to the data gathered from the key-informant discussion, conservation of medicinal plants in the area faces many challenges such as lack of access to land, fund, government policies and lack of conservation awareness.
\end{abstract}

DOI: $\underline{\text { https://dx.doi.org/10.4314/jasem.v25i12.11 }}$

Copyright: Copyright (C) 2021 Abisoye et al. This is an open access article distributed under the Creative Commons Attribution License (CCL), which permits unrestricted use, distribution, and reproduction in any medium, provided the original work is properly cited.

Dates: Received: 22 August 2021; Revised: 17 September 2021; Accepted: 06 October 2021

Keywords: Medicinal plants Use, Challenges, Conservation, Sustainability, Livelihood

The extent of the medicinal plant trade is largely unaccounted for in formal national and provincial statistics in many countries across the world, as records of sales transactions are seldom kept and the trade is often illicit in nature (Dold and Coks, 2002). In most African traditional societies, herbal remedies were often prepared as crude extract of medicinal plant organs such as leaves roots, flowers and barks (Telefo et al., 2011; Choudoury et al., 2013). Traditional medicine (TM) is defined as the sum total of knowledge, skills and practices based on the theories, beliefs and experiences indigenous to different cultures that are used to maintain health, as well as to prevent, diagnose, improve or treat physical and mental illnesses" (WHO, 2013). The importance of medicinal plants in household income is not well known due to the absence of a systematic and rigorous data collection system at national level in many developing countries (FAO, 2012). Nigeria as a country is richly endowed with indigenous plants, which are used in herbal medicine to cure diseases and heal injuries (Okwu, 2007; Dike and Obembe, 2012). However, as result of several human activities from overharvesting, deforestation, desertification, and global warming to mention a few, medicinal plants are faced with the serious problem of extinction (Kankara et al. 2015). Earlier, Shingu (2005) listed poverty as one of the challenges in conservation of medicinal plants. Orji et al. (2013) also listed over - exploitation of medicinal plant species, habitat destruction, financial problems, lack of proper education of the masses and prioritization of species to be conserved as some of the major problems facing medicinal plant conservation in Anambra state of Nigeria. This study therefore attempted to bridge some of the gaps in the understanding of the role that medicinal plants might play in the livelihoods of the urban poor and challenges faced towards medicinal plant conservation from the respondent point of view. Conservation of many economic natural resources faces challenges in phase of poverty, understanding their contribution, values, conservation challenges, might help in the development of programs alongside with the humans that use them to ensure their sustainability. The research on which this paper is based assessed the contribution of the medicinal plant trade and challenges affecting its conservation in Ibadan and Ogbomosho metropolis, Oyo state, Nigeria. The specific objectives are: 1) evaluate the contributions of the sales of traditional medicinal plants to the livelihoods of the traders in the study area 2) assessed the challenges militating against use, sustainability, and conservation strategy as perceived by the respondent. 


\section{MATERIALS AND METHODS}

Description of the study area: The study was carried out in Ibadan and Ogbomoso metropolis which are both situated in Oyo state, Nigeria.

Method of Data Collection: This study targeted the medicinal plant traders and practitioners as the respondent in Ogbomoso and Ibadan metropolis. In this regards, purposive random sampling technique was used in the selection of the targeted respondent. Four markets were purposively selected in Ibadan (Oba, Oranyan, Oje, Bode) and three markets were selected in Ogbomoso metropolis (Jagun, Akande, Kajola) based on the availability and popularity of market for medicinal plants using semi-structured questionnaire. Ibadan has much market for the sales of medicinal plant while Ogbomoso has few. 40 copies of the trader's questionnaire were retrieved at Ibadan metropolis, while 27 copies were retrieved from Ogbomoso metropolis making 67 retrieved questionnaires in total.
Method of Data Analysis: The retrieved questionnaires were coded using statistical package for social analysis and analyzed using descriptive statistics.

\section{RESULT AND DISCUSSION}

Socioeconomic characteristics the respondent: The result revealed that majority of respondents had the primary level of Education and had been in the business for more than 10years, while some did not attend school at all (Table 2). This shows their high dependency on medicinal plants for livelihood support. Igwillo U.C, et al (2019) suggested that community members should be provided with education on environmental conservation starting with the lowest levels of education. The research findings also revealed that the age distribution of traders with the highest frequency involved in medicinal plant trade were 50 years and above in Ogbomoso metropolis and 40-50 years in Ibadan metropolis, This reveals that the older generation are more into the trade of medicinal plants as also observed in Ethiopia by Bekalo et al, 2009.

Table 2: Socio- economic characteristics of traders at Ibadan and Ogbomoso metropolis

\begin{tabular}{|c|c|c|c|c|c|}
\hline Criteria & Variant & $\begin{array}{l}\text { OGBOMOSO } \\
\text { Frequency }\end{array}$ & $\begin{array}{l}\text { METROPOLIS } \\
\text { Percentage }\end{array}$ & $\begin{array}{l}\text { IBADAN } \\
\text { Frequency }\end{array}$ & $\begin{array}{l}\text { METROPOLIS } \\
\text { Percentage }\end{array}$ \\
\hline \multirow[t]{5}{*}{ Age } & 20-30 years & 0 & 0 & 2 & 5 \\
\hline & $31-40$ years & 4 & 14.8 & 5 & 12.5 \\
\hline & $41-50$ years & 9 & 33.3 & 17 & 42.5 \\
\hline & $>51$ years & 14 & 51.9 & 16 & 40 \\
\hline & Total & 27 & 100 & 40 & 100 \\
\hline \multirow[t]{3}{*}{ Gender } & Female & 27 & 100 & 38 & 95 \\
\hline & Male & 0 & 0 & 2 & 5 \\
\hline & Total & 27 & 100 & 40 & 100 \\
\hline \multirow[t]{5}{*}{ Education } & No formal & 15 & 55.6 & 27 & 67.5 \\
\hline & Primary school & 5 & 18.5 & 4 & 10 \\
\hline & Secondary school & 6 & 22.2 & 6 & 15 \\
\hline & Traditional & 1 & 3.7 & 3 & 7.5 \\
\hline & Total & 27 & 100 & 40 & 100 \\
\hline \multirow[t]{4}{*}{ Religion } & Christian & 12 & 44.4 & 14 & 35 \\
\hline & Muslim & 15 & 55.6 & 21 & 52.5 \\
\hline & Traditional & 0 & 0 & 5 & 12.5 \\
\hline & Total & 27 & 100 & 40 & 100 \\
\hline \multirow[t]{4}{*}{ Marital status } & Single & 0 & 0 & 2 & 5 \\
\hline & Married & 27 & 100 & 35 & 87.5 \\
\hline & Widow & 0 & 0 & 3 & 7.5 \\
\hline & Total & 27 & 100 & 40 & 100 \\
\hline \multirow[t]{4}{*}{ Household size } & $<5$ & 2 & 7.4 & 2 & 5 \\
\hline & 6-10sizes & 20 & 74.1 & 29 & 72.5 \\
\hline & $>10$ & 5 & 18.5 & 9 & 22.5 \\
\hline & Total & 27 & 100 & 40 & 100 \\
\hline \multirow[t]{3}{*}{ Tribe } & Yoruba & 26 & 96.3 & 39 & 97.5 \\
\hline & Igbo & 1 & 3.7 & 1 & 2.5 \\
\hline & Total & 27 & 100 & 40 & 100 \\
\hline \multicolumn{6}{|c|}{ Duration of occupation } \\
\hline & $<5$ years & 1 & 3.7 & 1 & 3.7 \\
\hline & $5-10$ years & 1 & 3.7 & 3 & 3.7 \\
\hline & $>10$ years & 25 & 92.6 & 36 & 92.6 \\
\hline & Total & 27 & 100 & 40 & 100 \\
\hline
\end{tabular}


This might be related to the waning of interest of the young generation on indigenous knowledge. Different studies in different areas showed that medicinal plant knowledge and transfer of knowledge to the young generation have been affected by modernization (having access to modern education and health service) and environmental change (Hillenbrand, 2006). In both metropolises, the respondent gender with the highest population were female with $100 \%$ in Ogbomoso while Ibadan has $95 \%$ for female and $5 \%$ for male. Delbanco (2017) also revealed in Kenya that women are traders of medicinal plants. This could be because of women dependency on natural resources as a form of livelihood and their use of health care natural products.

Contributions of Sales of Traditional Medicinal Plants to Livelihoods of Traders in Study Area: Income from medicinal plant trade: From figure 1, the income from the trade of medicinal plants was seen to vary, however the highest frequency earns above 50,000 in Ogbomoso metropolis while in Ibadan metropolis, traders who earn between 20,000 and 30,000 were of high frequency. Though the income from the trade seems low but it does meet their daily needs and cover expenses of childcare, child education, feeding and related expenses which some said to have built a portable house through the sales of medicinal plant.

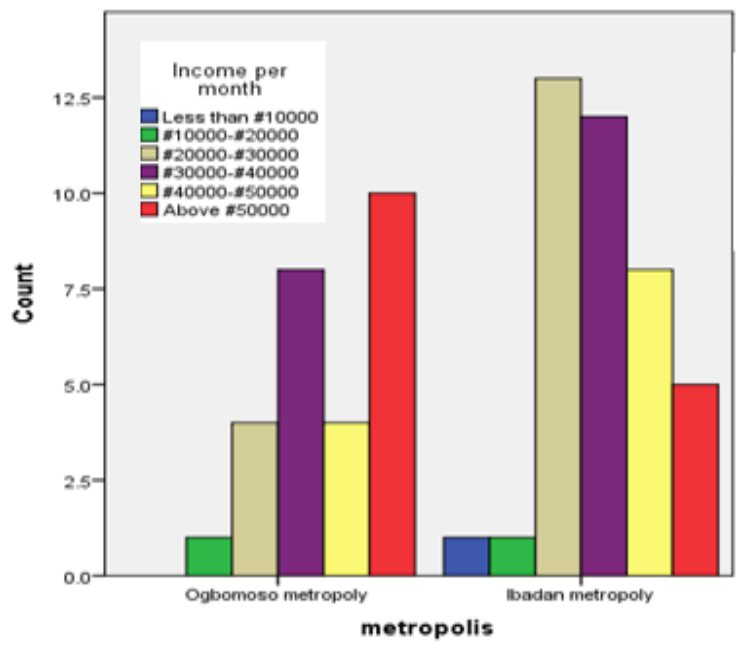

Fig 1: Income from the sales of medicinal plants

Also, from the study areas, it was discovered that the high sales of medicinal plants by the traders and practitioners is based on their dept of plant knowledge, success stories for people to recommend them, level of education and branding. The debt of knowledge has the highest percentage as revealed in figure 1 . The medicinal plants trade generates income for the traders in elevating their living standard and the economic status and serve as an access to the provision of materials in the provision of traditional health care services.

Challenges Militating Against Use, Sustainability, And Conservation Strategy As Perceived By Respondent: Challenges Militating against Use: Findings revealed as represented in figure 2, that the challenges militating against use as said by the practitioners was the fear by the users towards the use and safety of medicinal plants on their body system. Majority of the complaint by customer were the bitter taste, odour and the right dosage to be used by them. Result shows that dosage has the highest percentage $(75 \%)$ in both metropolis and bitter taste was $25 \%$ as a challenge towards use as conform to (Sofowora, 1982) that Lack of standardization and precision on dosage and quality control is seen as one of the main disadvantages of traditional medicine as summarized from various sources. Mafimisebi et al. (2013) observed that standards and regulations are still not fully developed and operational for the Nigerian herbal, medicinal and aromatic plants (HMAP) market. Adulteration of herbal drugs is a challenge in the use of medicinal plants. These challenges can be an avenue for research organization to collaborate with medicinal plant users in the development of programs that will enhance conservation and their sustainability.

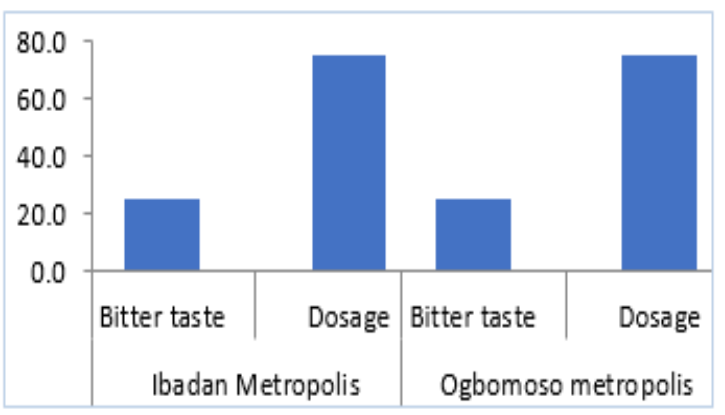

Fig 2: Challenges militating against uses

Challenges faced in ensuring sustainability of medicinal plants: Challenges faced in ensuring the sustainability of medicinal plants in Ogbomoso metropolis traders as represented in figure 3 was that $14.8 \%$ sees lack of access to land has a major problem to cultivate medicinal plants and that government land are not secure to plant as it can be deforested for urbanization while $81.5 \%$ said lack of funds to purchase land or cultivate medicinal plants and 3.7\% said government policies is the challenged faced in ensuring plants sustainability. In Ibadan metropolis, 5.0 said lack of access to land, $92.5 \%$ said fund and $2.5 \%$ said government policies. Rao et al., (2004), observed that lack of land is the most significant 
constraint to medicinal plant cultivation. The practitioners mentioned that they do purchase medicinal plant from the market and there is no need to cultivate medicinal plants on their own since it is available at the market as conformed to (Igwillo et al 2019) that lack of proper education of the masses and prioritization of species to be conserved, lack of conservation programmes, is a challenge in ensuring these plants sustainability. Different studies had observed loss of forest land to agriculture, urbanization and overexploitation of forest resources as factors forcing traditional healers to travel long distances before obtaining important and scarce plant materials for their preparation (Omobuwajo et al., 2008, Kisangau, 2004,). Egharevba and Ikhatua (2008) observed that lack of conservation measures will increase the number of endangered species resulting in individual extinction of numerous plant taxa that are useful as herbal remedies.

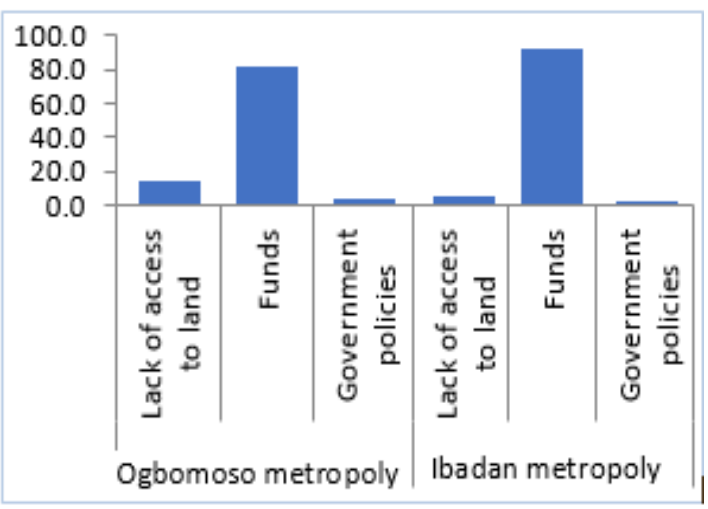

Fig 3: Challenges faced in ensuring plants sustainability

Earlier, Gideon (2009) noted that in recent time several efforts have been made in Nigeria with regards to documentation of traditional medicine knowledge relating to plant species. Direct and coherent efforts to conserve plant species have received relatively little policy attention and research support (Leaman, 2004). This has not been a straightforward programme due to many problems that militate against it (Orji et al. 2013). It is therefore essential that we work towards conservation of this valuable plant resource, not just with the thought of preserving nature's bounty but for the well-being and livelihoods of indigenous local communities and the society at large, who depend on these resources (Igwillo et al 2019).

Respondents' view of the situation of plant availability, reasons for the change in availability, and areas where they find the plant for harvesting across the metropolis for the past 10 years: A single data was gathered from respondent across all metropolis to know their view of plant availability, reasons for the change in availability, and areas where they find the plant for harvesting. From the study area as represented in figure $4,60.21 \%$ of respondents said the plant was moderately available compared with the past 10 years, while $57.37 \%$ and $35.57 \%$ mentioned the difficult and easy availability, respectively. Most of the respondents mentioned forest $(83.11 \%)$ and grazing lands $(59.72 \%)$ as the major areas for plant collection, while $(54.31 \%)$ of the respondents mentioned farmlands and homesteads $(23.12 \%)$ as the area of plant collection. Furthermore, the respondents agreed that there were places the plant was available in past years but not anymore which was caused by the change in land use to agriculture and building of structures $(91.01 \%)$, overexploitation $(85.11 \%)$, unsustainable harvesting methods $(67.28 \%)$, and increase in demand (70.24\%) (Figure 4). Several significant conservation challenges mentioned were noticeable due to change in land use to agriculture, overexploitation, unsustainable harvesting methods, and increase in demand for medicinal plants, as reported by (Abdullahi AA. 2011, Aiyeloja AA 2012, Bhattacharyya R, et al 2006). According to the results above, conservation measures such as the provision of education and awareness, reducing excessive harvesting, the government setting rules and regulations for the conservation of medicinal plants, and ensuring proper land use, land-use planning and domestication aligned with Aiyeloja AA (2012) should be adopt as an approach for sustainability.

Conclusion: This study justified that medicinal plants trade contribute to the livelihood of traders in Ogbomoso and Ibadan metropolis. Though the income seems little, but it is used to meet up their daily needs. However, its sustainability seems threaten as the location for the collection of medicinal plants becomes farer due to increase in demand, change in land use (agriculture and urbanization), overexploitation and unsustainable harvesting. The study found that there was a dearth of information of the reasons for conservation strategies in the study region, implying that greater efforts should be made to raise conservation consciousness. Biodiversity conservation is incompatible with poverty in general, especially when it comes to natural resources with economic value, such as medicinal plants. Major protected areas have been encroached upon as a result of bad administration, and conservation efforts are incompatible with poverty reduction in most cases. Conservation of natural resources must be integrated into economic growth programs, especially at the local level. Understanding medicinal plants' contribution to livelihood and economic growth is crucial for sustainable design, development, and implementation, not just for conservation, but also for welfare and 
economic growth, especially for people who rely solely on them for revenue. Financial support, frequent training, and informal education, according to the respondents, would help alter the medicinal plant trading sector to sustain livelihoods. The respondent's opinions should be taken into account by the government, research institutes, and other stakeholders.

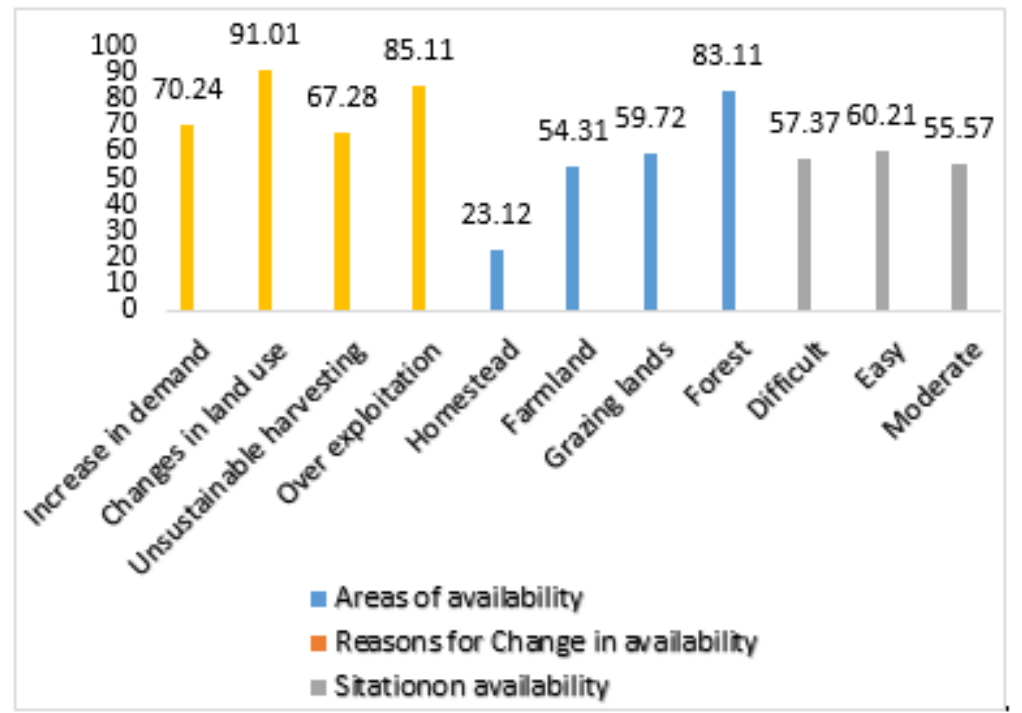

Fig 4: Respondents' view of the situation of plant availability, reasons for the change in availability, and areas where they find the plant for harvesting

Acknowledgement: This was an undergraduate project conducted at the Federal University of Technology Akure. The authors would like to appreciate the medicinal plant traders and practitioners in Ogbomoso and Ibadan respectively where the primary data were collected, for their patience and time in answering the question.

\section{REFERENCES}

Abdullahi AA. (2011). Trends and challenges of traditional medicine in Africa. Afr. J. Traditional. Complementary and Alternative Medicines. 8(5): 115-123.

Aiyeloja AA, Bello OA, Akintayo ME. (2012). Evaluation of common medicinal plants used for family planning in Nigeria. J. Appl. Res. 2(1): 15.

Bekalo, T.H., S.D Woodmatas and Z.A Woldemariam, (2009). An ethnobotanical study of medicinal plants used by local people in the lowlands of Konta Special Woreda, Southern nations, nationalities and peoples regional state, Ethiopia. J. Ethnobiology. Ethnomedicine 5:26

Bhattacharyya R, Bhattacharya S, Chaudhuri S. (2006). Conservation and documentation of the medicinal plant resources of India. Biodiversity and Conservation. 15:2705-2717.

Choudhury, S., Sharan, L., and Sinha, M. P. (2013). Screening of Some Commonly Used Medicinal Plants against Enteric Human Pathogen Vibrio cholerae, European. J. Med. Phy. 9 (3), 1-6.

Delbanco, AS., Burgess, N.D; Cuni-Sanchez, (2017) A. Medicinal Plant Trade in Northern Kenya: Economic Importance, Uses, and Origin Econ. Bot. 71. 13-31

Dike IP, Obembe OO. (2012). Towards conservation of Nigerian medicinal plants. Journal of Medicinal Plants Research. 6(19): 3517-3521

Dold, A.P. and Cocks, M.L. (2002). The trade in medicinal plants in the Eastern Cape, South Africa. South African J. Sci. 98, 589-597.

Egharevba RKA, Ikhatua MI. (2008). Ethno-medical uses of plants in the treatment of various skin diseases in Ovia North East, Edo state, Nigeria. Res. J. Agric. Bio. Sci. 4(1): 58-64.

FAO, (2012). Historical and Projected Population of Nigeria. United Nations Food and Agriculture 
Organization, http://www.fao.org Accessed: October 21, 2017

Gideon EC. (2009). Digitization, Intellectual Property Rights and Access to Traditional Medicine Knowledge in Developing Countries - the Nigerian Experience. A Research paper prepared for International Development Research Centre (IDRC), Ottawa, Canada.

Hillenbrand E (2006). 'Improving traditional convectional millbury care servicesedicine collaboration: personal respective from cameroonian traditional practitioners'. Nordic J. Afr. Studies, 15(1): 1- 50.

Igwillo U.C, Ola-Adedoyin A.T, Abdullahi M.M and Chukwuemeka A.E. (2019). A Review Of Opportunities And Challenges In Conservation And Use Of Medicinal And Aromatic Plants In Nigeria. Inter. J. Adv. Res. 7(4), 770-778

Kankara SS, Ibrahim MH, Mustafa M, Go R. (2015). Ethnobotanical survey of medicinal plants used for traditional maternal healthcare in Katsina state, Nigeria. South African J. Botany. 97: 165175.

Kisangau, D. and J. O Kokwaro. (2004). Use of Medicinal Plants: Kenya in Sharing Innovative Experiences, United Nations Development Programme, New York, 9: 60

Leaman DJ. (2004). The Global Strategy for plant conservation - What can it mean for medicinal plants? Newsletter of the medicinal plant specialist Group, volume 9/10
Mafimisebi TE, Oguntade AE, Ajibefun IA, Mafimisebi OE, Ikuemonisan ES. (2013). The expanding market for herbal, medicinal and aromatic plants in Nigeria and the international scene. Med Aromat Plants. 2(6):1-9.

Omobuwajo, O. R., G .O. Alade and A. Sowemimo. (2008). Indigenous Knowledge and practices of women herb sellers of Southwestern Nigeria. Indian J. Traditional Knowledge 7(3): 505-510

Orji EC, Onwughalu GI, Nweke IA. (2013). Problems associated with conservation of medicinal plants in Anambra State. J. Environ. Sci. Toxicol. Food Tech. 2(6):61-63.

Rao, M.R., M.C. Palada and B. N. Becker. (2004). Medicinal and aromatic plants in Agro forestry systems (61): 107-122

Shingu GK. (2005). Ownership and sustainability issues of botanical medicines. Ethnobotanical Res. Applicat. 3:017-023.

Sofowora EA (1982). The State of Medicinal Plants' Research in Nigeria. Ibadan University Press, Nigeria, p. 404

Telefo, P. B., Lienou, L. L., Yemele, M. D., Lemfack, M. C., Mouokeu, C., Goka, C. S., Moundipa, F. P. (2011). Ethnopharmacological survey of plants used for the treatment of female infertility in Baham, Cameroon. J. Ethnopharmacology, 136(1), 178-187.

World Health Organisation (2013). The WHO Traditional Medicine Strategy 2014-2023 